\title{
Pengembangan Sistem E-Learning untuk Meningkatkan Keterampilan Berpikir Kritis Mahasiswa Pendidikan Fisika
}

\author{
Pramudya Dwi Aristya Putra, Sudarti \\ Program Studi Pendidikan Fisika, FKIP, Universitas Jember \\ Bumi Tegal Boto, JL. Kalimantan No. 37 Jember- Indonesia \\ Pramudya.fkip@unej.ac.id
}

\begin{abstract}
Abstrak - Penelitian bertujuan mengembangkan perangkat pembelajaran untuk meningkatkan keterampilan berpikir kritis mahasiswa melalui sistem e-learning. Metode yang digunakan adalah 2R2D yang dikembangkan oleh Willis. Tahapan penelitian ini terdiri dari pendefinisian, perencanaan dan menyebarluaskan. Data diperoleh melalui pretest, angket dan posttest dengan bentuk instrument berupa lembar angket dan butir soal berpikir kritis. Subyek penelitian adalah 35 Mahasiswa Program Studi Pendidikan Fisika Universitas Jember yang memprogram pada mata kuliah Fisika Sekolah I. Hasil indikator yang dikembangkan dalam berpikir kritis adalah interprestasi, analisis, evaluasi dan inferensi. Validasi ahli menjukkan bahwa perangkat yang dikembangkan adalah cukup valid. Terjadi peningkatan rata-rata pada uji coba perangkat. Berdasarkan penelitian didapatkan simpulan bahwa perangkat pembelajaran dengan sistem e-learning meningkatkan keterampilan berpikir kritis mahasiswa.
\end{abstract}

Kata kunci: Sistem e-learning, keterampilan berpikir kritis

\begin{abstract}
The research aims to develop a learning tool to improve students critical thinking skills through e-learning system. 2R2D method developed by Willis is used as a research method. The research steps are defining, planning and disseminate. Data were obtained through a pretest, posttest questionnaire and the form of instruments were questionnaire and critical thinking test. Subjects were thirty five Physics Education Program Study at Jember of University who do programming in the School Physics I course. The result of the developed indicators in critical thinking are interpretation, analysis, evaluation and inference. Experts has validate that the developed learning tool is valid, with an increase of an average value on a test phase. The result concluded that the e-learning system will improve students critical thinking skills.
\end{abstract}

Key words: e-learning system, critical thiking skills

\section{PENDAHULUAN}

Ilmu Fisika merupakan ilmu yang mempelajari hubungan gejala-gejala alam. (Serway, 2009) lmu fisika didasarkan pada pengamatan secara eksperimental dan pengukuran kuantitatif. Tujuan utamanya adalah untuk mencari sejumlah hukum-hukum tersebut demi mengembangkan teori-teori yang dapat memprediksi hasil-hasil percobaan selanjutnya. Sehingga dengan dasar ilmu fisika dapat mengembangkan teknologi serta berbagai ilmu yang banyak digunakan dalam menganalisis peristiwa alam.

Mata pelajaran Fisika di Indonesia mulai diajarkan dari tingkat dasar sampai dengan tingkat pendidikan tinggi. Seharusya dengan lama studi fisika sedemikian hingga terbentuklah pola pembelajaran yang berorientasi pada pendekatan sains. Akan tetapi hasil penelitian TIMSS (Trends in Mathematic and Science Study) 2011 pada bidang studi Fisika Indonesia memperoleh nilai 397. Nilai tersebut dibawah nilai rata-rata yaitu 500. Proporsi kemampuan berpikir siswa di Indonesia digambarkan bahwa kemampuan memahami lebih tinggi jika dibandingkan dengan kemampuan menerapkan dan menalar (Rofiah,2013). Berdasarkan taxonomy Bloom kemampuan memahami dan menerapkan termasuk dalam katagori kemampuan berpikir tingkat rendah (lower order thiking) sedangkan kemampuan menalar masuk dalam katagori kemampuan berpikir tingkat tinggi (high order thinking).

Nilai yang telah didapatkan dalam keikutsertaan Indonesia sebagai partisipan TIMSS adalah hasil dari proses pembelajaran yang telah dilakukan selama ini. Proses pembelajaran fisika ditekankan sekadar berorientasi pada penyampaian materi saja. Guru tidak melihat sisi lain bahwa Fisika merupakan pembelajaran kompleks yang melibatkan proses berpikir. Proses berpikir inilah yang akan menghantarkan siswa memiliki keterampilan berpikir tingkat tinggi.

Salah satu keterampilan berpikir tingkat tinggi adalah berpikir kritis. (Johnson,2007) menyatakan bahwa berpikir kritis adalah suatu proses yang terintegrasi memungkinkan seseorang untuk mengevaluasi bukti, asumsi, logika dan bahasa yang mendasari pemikiran orang lain. Definisi lain tentang berpikir kritis adalah proses berpikir mendalam tentang suatu informasi melalui kegiatan penyelidikan, explorasi, eksperimen dan lain-lain untuk memperoleh kesimpulan yang akurat sehingga terjadi pengkonstruksian pengetahuan secara bermakna (Helperida,2014). Proses berpikir kritis dapat dilakukan dengan tahapan sebagai berikut: interpresatsi, analisis, evaluasi, inferensi, explanasi, dan regulasi diri. Kemampuan berpikir kritis ini dikembangkan pada mata pelajaran fisika guna memberikan pengalaman siswa untuk dapat memahami dan mengklarifikasi data, 
mengumpulkan suatu informasi dan mengkombinasinya, membuat suatu argument dengan langkah yang sistematis serta menilai kelayakan pendapat.

Mulai merebaknya layanan internet menjadikan proses pembelajaran semakin mudah terakses. Perubahan inilah yang mendasari pergesean pendidikan di abad 21. Belajar bisa dilakukan kapanpun dan dimana saja. Sebagai pendidik setidaknya harus tanggap terkait dengan perubahan media pendidikan ini. Pelaksanaan pembelajaran dengan berbantuan internet ini lebih dikenal dengan pembelajaran online. Pembelajaran online telah dipromosikan di berbagai jenjang pendidikan. Pembelajaran online sendiri merupakan pembelajaran dengan biaya yang lebih efektif dan nyaman dibandingkan dengan lingkungan pembelajaran tradisional (Richardson,2003). Penerapan model pembelajaran online bisa dilakukan dengan online full learning (tanpa tatap muka antara pengajar dan siswa) atau dilakukan blended lerning (hanya sebagagian waktu dilakukan secara online).

Berbagai tempat sekolah atau lembaga pendidikan formal yang lebih tinggi menekankan nama online learning berupa e-learning. E - learning sendiri lebih dikenal masyarakat sebagai media untuk melaksanakan pembelajaran jarak jauh. Melalui penggunaan e-learning membuat siswa dan guru membuat lebih interactive, betatap muka online, dapat memvisualisasi dan memberikan authentic area (Nuangchalem,2014). Hal ini membuat proses pembelajaran berlangsung secara berkelanjutan. Guru mampu memantau aktivitas peserta didik melalui e-learning ini. Oleh sebab itu, penelitian ini bertujuan mengembangkan perangkat pembelajaran untuk meningkatkan keterampilan berpikir kritis mahasiswa program studi pendidikan fisika melalui sistem elearning.

\section{METODE PENELITIAN/EKSPERIMEN}

Penelitian ini merupakan penelitian pengembangan dengan desain Recursive Reflective Desain and Development (R2D2) yang dikembangkan oleh Willis (1995). Desain ini digunakan karena bersifat reflektif, rekursif, kolaboratif dan berkembang sehingga memberikan kesempatan peneliti dan pihak-pihak yang tekait untuk mengembangkan produk pembelajaran sesuai dengan kebutuhan secara terus menerus sampai ditemukan produk yang dianggap paling tepat, efektif dan efisien.

Prosedur penelitian pengembangan ini terdiri dari tiga tahap: (1) pendefinisian, (2) perencanaan dan (3) menyebarluaskan. Tahap pendefinisian dilakukan dengan Studi pendahuluan masalah yang kontekstual, kerja sama tim dan solusi masalah secara progersif. Tahap perencanaan meliputi pada kegiatan mempelajari konteks pembelajaran, memilih desain penggunaan media, menentukan strategi evaluasi dan menciptakan desain produk pengembangan. Penyebaran dilakukan dengan aktivitas evaluasi otentik dan pengemasan media sesuai konteks.
Uji produk dilakukan dengan uji expert dan Uji pengguna. Uji ahli adalah teman sejawat yaitu 2 dosen yang dipilih berdasarkan keahlian pengembangan media. Uji pengguna diberikan kepada 20 mahasiswa pendidikan fisika FKIP universitas Jember yang telah memprogram mata kuliah Fisika Sekolah I. Hasil dari kegiatan uji produk ini digunakan sebagai perbaikan produk untuk menghasilkan produk yang lebih baik.

Subyek penelitian sebagai uji coba terbatas dilakukan pada 40 mahasiswa pendidikan fisika FKIP universitas Jember yang memprogram mata kuliah Fisika Sekolah I. Pengumpulan data dilakukan dengan memberikan angket dan lembar saran kepada ahli yang meliputi tentang ketepatan konsep materi, penyajian materi, bahasa, lay out, kemudahan akses, sinkronisasi media, kenyamanan, kejelasan gambar/grafik, evaluasi. Sedangkan untuk uji pengguna diberikan lembar angket dan test melalui elearning. Kegiatan ini dimaksudkan untuk mendapatkan nilai validitas dan reliabilitas sistem e-learning yang telah dikembangkan.

Uji Coba terbatas dilakukan dengan mengaplikasikan media pembelajaran berupa sistem e-learning untuk mengetahui tingkat kemampuan mahasiswa dalam berpikir kritis. Metode yang digunakan adalah pre test post test group dengan melihat perbandingan nilai ratarata setiap indikator dalam berpikir kritis. Untuk melihat efektifitas hasil belajar maka dilakukan perhitungan Gain ternormalisasi dengan persamaan:

$g=\frac{S_{f}-S_{i}}{100-S_{i}}$

Keterangan:

$g \quad=$ rata-rata gain ternormalisasi

$S_{f} \quad=$ rata-rata skor test akhir

$S_{i} \quad$ = rata-rata skor test awal

Dengan interprestasi nilai gain

Tabel 1. Interprestasi nilai gain

\begin{tabular}{cc}
\hline Nilai gain & Interprestasi \\
\hline $\mathrm{g} \geq 0,7$ & Tinggi \\
$0,7>\mathrm{g} \geq 0,3$ & Sedang \\
$\mathrm{g}<0,3$ & rendah \\
\hline
\end{tabular}

\section{HASIL DAN PEMBAHASAN}

Langkah awal yang dilakukan dalam penelitian yaitu tahap pendefisian. Tahap pendefinisian ini fokus pada penentuan indikator. Deskripsi indikator yang telah dirumuskan disajikan dalam tabel 2.

Tabel 2. Rumusan indikator pelaksanaan berpikir kritis

Indikator Kegiatan

Menginterprestasi Membandingkan variasi data, kriteria, aturan atau prosedur

Menganalisis Mengidentifikasi bukti-bukti aktual dan menghubungkan antara konsep

Mengevaluasi Menilai kredibilitas suatu pernyataan atau deskrisi

Inferensi Mempertanggung jawabkan pernyataan
berdasarkan elemen yang dibutuhkan terkait menyimpukan suatu masalah (mengabil keputusan) 
Berdasarkan tabel 2 bahwa indikator yang dikembangkan dalam penelitian ini ada 4 dengan masingmasing masalah 10 soal. Bentuk soal yang diberikan berupa pilihan ganda dan uraian yang membutuhkan pemikiran lanjut atau dibutuhkan suatu pembuktian.

Setelah dirumusakan indikator pencapain berpikir kritis langkah selanjutnya mensinkronkan instrumen keterampilan berpikir kritis dengan sistem e-learning. Elerning yang digunakan menggunkan softwere moodle. Moodle merupakan salah satu softwere yang dikembangkan berbasis Learning Management System (LMS) open source sehingga bisa dikembangkan kapanpun terus menerus sesuai fasilitas yang ditawarkan oleh penyedia layanan. Untuk mencapai indikator dalam berpikir kritis maka layanan e-learning yang digunakan adalah: forum, chating, assigment, dan quiz. Empat layanan ini dapat digunakan sebagai bentuk tanggapan mahasiswa terkait dengan tiap masalah yang dikembangkan. Gambaran proses sinkronisasi perangkat yang dikembangkan dengan sistem e-learning adalah seperti ditunjukkan dalam Gambar 1.

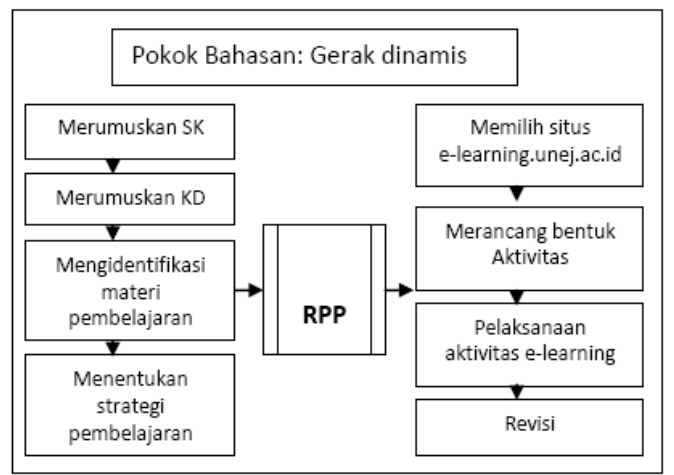

Gambar 1. Desain pembelajaran menggunkan sistem e-learning

Setelah proses sinkronisasi dengan sistem e-learning maka dilakukan proses validasi uji expert. Hasil uji expert ini disajikan dalam Tabel 3.

Tabel 3. Hasil Uji expert

\begin{tabular}{lccc}
\hline \multicolumn{1}{c}{ Aspek } & Rata-rata & Validitas & Kategori \\
\hline Kelayakan Isi & 3,53 & & \\
Kebahasaan & 3,48 & & \\
Sajian & 3,80 & 3,44 & Cukup valid \\
Kegrafisan & 3,33 & & \\
Akses & 3,00 & &
\end{tabular}

Berdasarkan hasil analisis penilaian kedua validator menunjukkan bahwa instrumen pengukuran berpikir kritis mahasiswa melalui sistem e-learning adalah cukup valid. Penilaian ini merupakan rata-rata kelima aspek meliputi kelayakan isi, kebahasaan, sajian, kegrafisan dan kemudahan akses. Selain menggunakan validasi ahli dilakukan pula validasi pengguna. Validasi ini dilakukan guna menguji validitas dan taraf reliabilitas instrument. Sebelum dilakukan uji pengguna, dilakukan uji Basic computer literacy. Uji ini dilakukan agar mendapatkan data bahwa peserta uji pengguna telah paham dan menguasai penggunaan kompter dan internet
(Tufan,2014). Uji basic compter literacy ini dilakukan melalu online www.wisiq.com. Hasil yang diperoleh dari uji basic computer litercay ini adalah baik untuk penggunaan kompter dan internet. Hasil uji validasi disajikan dalam tabel 4.

Tabel 4. Penerimaan item tes uji coba instrumen

\begin{tabular}{lcc}
\hline \multicolumn{1}{c}{ Katagori } & Jumlah Soal & Persentase \\
\hline Diterima & 25 & $62,5 \%$ \\
Direvisi & 13 & $32,5 \%$ \\
Ditolak & 2 & $0,5 \%$ \\
\hline
\end{tabular}

Setelah dilakukan uji coba pengguna maka dilakukan proses revisi dalam intrumen test. Intrumen test ini kemudian digunakan dalam pengambilan data pada mata kuliah fisika sekolah I. Model pembelajaran yang digunakan dalam pembelajaran adalah Problem Based Instruction dengan sistem e-learning sebagai media dalam proses pembelajaran.

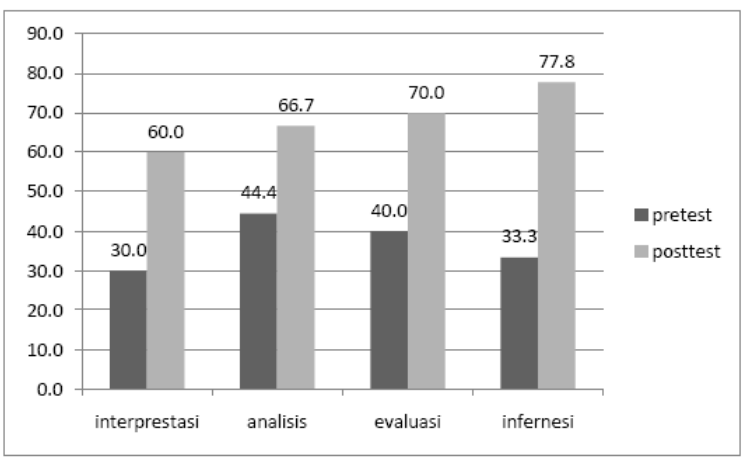

Gambar 2. Perbandingan nilai pretest dan posttest mahasiswa

Gambar 2 menunjukkan nilai pretest dan posttest mahasiswa tiap indikatornya. Nilai posttest diperoleh setelah melakukan aktivitas pembelajaran menggunakan blended learning. Aktivitas yang dilakukan dengan menggunakan e-learning adalah forum, chating, assigment dan quis. Kegiatan forum dilakukan dengan meninggalkan masalah kepada siswa terkait dengan kasus pembelajaran gerak dinamis. Sebagai contoh pada tahapan analisis: terdapat suatu kesimpulan yang diperoleh dari percobaan hukum I Newton dengan hasil simpulan "setiap benda akan diam atau bergerak lurus beraturan apabila resultan gaya yang bekerja padanya bernilai nol" benarkah hukum I Newton menyatakan hal ini bagaimankah tanggapan saudara? Setelah meninggalkan masalah dalam forum tersebut maka mahasiswa memberikan tanggapan di ruang forum virtual dengan memberikan alasan dan bukti-buktinya. Kegiatan chating bisa dilakukan apabila pengguna yang sama sedang online. Kegiatan ini dilakukan oleh mahasiswa apabila sedang melakukan diskusi dalam sistem elearning. Assigment diberikan apabila masalah perlu dilakukan analisis dan evaluasi melalui percobaan sederhana. Hasil dari analisis dan evalusai bisa diunggah sedangkan kegiatan pengajar memberikan feedback terhadap hasil laporan yang telah diunggah.

Penetapan pengembangan indikator di dalam penelitin ini menggambarkan kemampuan mahasiswa dalam 
menerima masalah dan menyelesaikan dengan proses berpikir tingkat tinggi. Sejalan dengan pernyataan (King, 2014). bahwa keterampilan berpikir tingkat tinggi termasuk didalamnya adalah berpikir kritis, berpikir logis, berpikir reflektif, metakognitif dan berpikir kreatif. Taxonomy Bloom menempatkan kegiatan analisis dan sintesis, evaluasi dan create diletakkan pada hirarki yang lebih tinggi jika dibandingkan pada ingatan, pemahaman dan penerapan. Karena pada ranah tersebut membutuhkan tahap keterampilan termasuk berpikir kritis. Pada dasarnya tujuan diberikan keterampilan berpikir mahasiswa adalah untuk memecahkan masalah di fisika sesuai dengan pendekatan science. (Ramos,2013) menegaskan bahwa analisis dan evaluasi merupakan suatu keterampilan yang diasosiakan sebagai langkah untuk memecahkan suatu masalah.

Hasil yang didapatkan bahwa kemampuan mahasiswa dalam menginfernsi suatu masalah lebih tinggi daripada 3 indikator yang lainnya. Mahasiswa telah berani mengambil keputusan yang dirasa tepat berdasarkan bukti-bukti yang telah mereka dapatkan. Bukti ini berdasarkan hasil diskusi yang mereka ikuti secara berkelanjutan melalui kegiatan e-learning. Desian ruang diskusi dibuat fleksibel antara mahasiswa dan dosen sehingga mereka saling berhubungan dan mengikuti diskusi berdasarkan pengalaman, perspektives, pembelajaran dan menyampaikan pertanyaan yang lain dengan nyaman (Ruane,2011). Menurut teori kognitif Piaget berdasarkan pengalaman yang didapat mahasiswa ini maka terjadilah proses penataan adaptasi dari skema, asimilasi sampai pada akhirnya adanya akomodasi (Putra,2011).

Nilai rata-rata terendah mahasiswa didapatkan pada indikator interprestasi. Pada kegiatan ini mahasiswa mengamati dan mengkritik kejanggalan-kejanggalan data yang disajikan, hubungan antara besaran dan kelengkapan bukti pendukung. Pada indikator ini mahasiswa menyelesaiakan masalah melalui kegiatan quiz. Agar mahasiswa dapat menginterprestasikan suatu masalah maka diperlukan kecermatan, kejelasan, konsisten, dan jeli dalam menentukan variabel.

Perbandingan rata-rata nilai keterampilan berpikir kritis mahasiswa berdasarkan gambar 2 diperoleh total nilai pretest adalah 37 dan setelah secara melaksanakan proses pembelajaran dengan menggunakan e-learning diperoleh nilai posttest sebesar 68. Untuk melihat efektivitas produk didapatkan perhitungan nilai gain ternormalisasi sebesar 0,5 yang menunjukkan nilai sedang. Peningkatan rata-rata mahasiswa ini diperoleh karena adanya intensitas mahasiswa bertinteraksi baik secara langsung di kelas ataupun melalui e-learning. Selain itu melalui e-learning masalah yang disajikan juga actual dan mudah ditemui oleh mahasiswa.

\section{KESIMPULAN}

Perangkat yang dikembangkan melalui sistem elearning dapat meningkatkan keterampilan berpikir kritis mahasiswa. Dengan hasil uji validasi adalah 3,44 (cukup valid). Hasil nilai rata-rata mahasiswa dalam keterampilan berpikir kritis setelah proses menggunakan sistem e-learning adalah 68 dengan nilai gain ternormalisasi adalah 0,5. Nilai tersebut masuk dalam katagori sedang. Untuk penelitian selanjutnya penilaian tidak hanya ditinjau dari ranah kognitif saja akan tetapi perlu dikembangkan pula model instrument melalui elearning terkait afektif dan psikomotor siswa.

\section{UCAPAN TERIMA KASIH}

Terimakasih diberikan kepada Lembaga Penelitian Universitas Jember yang mendukung penelitian ini dengan pemberian dana DIPA Universitas Jember tahun Anggaran 2014.

\section{PUSTAKA}

[1] Serway. J, Fisika untuk Sains dan Teknik, Salemba Teknika, 2009.

[2] Rofiah E, Nonoh. S.A, E.Y. Ekawati. Penyusunan Instrumen Tes Kemampuan Berpikir Tingkat Tinggi Fisika Pada SMP, Jurnal Pendidikan Fisika, Vol.1, No. 2, 2013. pp $17-22$

[3] Johnson E.B, Contextual Teaching \& Learning, Menjadikan kegiatan Belajar-Mengajar Mengasyikkan dan Bermakna (terjemahan). Mizan Learning Center, 2007.

[4] Helperida. T, Keterampilan Berpikir Kritis, 2012. Website: http://kekeislearning.blogspot.com diakses tanggal 1 Meret 2014.

[5] Richardson and Jenefer C, Examining Social Presence in online Courses in Relation to Students' Perceived Learning and Satisfaction, JALN, Vol.7, No. 1, 2003, pp $68-88$

[6] Nuangchalerm P, K. Samkumduang, S. Uhwha, and P. Chansirisira, Implementing e-learning design courses in general education, Asian Journal of Education and Elearning, Vol. 2, No.4, 2014, pp 259 - 263

[7] Willis.J, A Recursive, Reflective Instructional Desaign Model Based on Contructivist - Interpretative Theory, Educational Technology, 1995

[8] Tufan. A, Zafer. C, Esad. E. Effectiveness of an Online Automated Evaluation and Feedback System in an Introductory Computer Literacy Course, Eurasia Journal of Mathematic, Science and Technology Education, Vol. 10, No. 5, 2014, pp $395-404$

[9] King FJ, L. Goodson, F. Rohani. Higher Thiking Skills definistion, teaching strategis, assessment, (online) Website: www.cala.fsu.edu diakses tanggal 1 Maret 2014.

[10] Ramos J.LS., B.B. Dolipas, B.B. Villamor, Higher Order Thinking Skills and Academic Performance in Physics of College Students: A Regression Analysis, International Journal of Innovative Interdisciplinary Research, Issue 4, 2013, pp $48-60$

[11] Ruane. R and Koku. E. F, Social Network Analysis of Undergraduate Education Student Interaction in Online Peer Mentoring Settings, MERLOT Journal of Online Learning and Teaching, vol.10, No.4. 2014, pp. $557-589$

[12] Putra.P.D.A, Pembelajaran Fisika dengan Model Inkuiri Terbimbing dan CTL ditinjau dari kemampuan berpikir abstrak dan motivasi brprestasi, M.Pd, Thesis. 2011. 